\title{
The religious statement of the Voortrekker Monument as a site of Afrikaner memory: Origin, composition and reception
}

\begin{tabular}{|c|c|}
\hline \multicolumn{2}{|l|}{$\begin{array}{l}\text { Author: } \\
\text { Dolf Britz }{ }^{1}\end{array}$} \\
\hline \multicolumn{2}{|c|}{$\begin{array}{l}\text { Affiliations: } \\
{ }^{1} \text { Department of Church } \\
\text { History and Church Polity, } \\
\text { Faculty of Theology and } \\
\text { Religion, University of } \\
\text { Pretoria, South Africa }\end{array}$} \\
\hline $\begin{array}{l}\text { Research Proj } \\
\text { Project Leader } \\
\text { Project Numb }\end{array}$ & $\begin{array}{l}\text { ect Details: } \\
\text { W.A. Dreyer } \\
\text { er: } 77370920\end{array}$ \\
\hline \multicolumn{2}{|c|}{$\begin{array}{l}\text { Description: } \\
\text { Prof. Dr Dolf Britz is } \\
\text { participating in the research } \\
\text { project, 'Justice and Human } \\
\text { Dignity. A Reformed } \\
\text { perspective', directed by } \\
\text { Dr Wim Dreyer, Department } \\
\text { of Church History and Church } \\
\text { Polity, Faculty of Theology and } \\
\text { Religion, University of Pretoria. }\end{array}$} \\
\hline \multicolumn{2}{|c|}{$\begin{array}{l}\text { Corresponding author: } \\
\text { Dolf Britz, } \\
\text { britz.dolf@gmail.com }\end{array}$} \\
\hline \multicolumn{2}{|c|}{$\begin{array}{l}\text { Dates: } \\
\text { Received: } 07 \text { June } 2018 \\
\text { Accepted: } 08 \text { Aug. } 2018 \\
\text { Published: } 27 \text { Nov. } 2018\end{array}$} \\
\hline \multicolumn{2}{|c|}{$\begin{array}{l}\text { How to cite this article: } \\
\text { Britz, D., 2018, 'The religious } \\
\text { statement of the Voortrekker } \\
\text { Monument as a site of } \\
\text { Afrikaner memory: Origin, } \\
\text { composition and reception', } \\
\text { HTS Teologiese Studies/ } \\
\text { Theological Studies } 74(3), \\
\text { a5142. https://doi.org/ } \\
\text { 10.4102/hts.v74i3.5142 }\end{array}$} \\
\hline \multicolumn{2}{|c|}{$\begin{array}{l}\text { Copyright: } \\
\text { (C) 2018. The Authors } \\
\text { Licensee: AOSIS. This } \\
\text { is licensed under the } \\
\text { Creative Commons } \\
\text { Attribution License. }\end{array}$} \\
\hline \multicolumn{2}{|l|}{ Read online: } \\
\hline 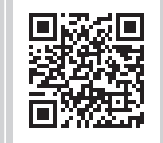 & $\begin{array}{l}\text { Scan this QR } \\
\text { code with your } \\
\text { smart phone or } \\
\text { mobile device } \\
\text { to read online. }\end{array}$ \\
\hline
\end{tabular}

The religious statement made by the Voortrekker Monument is part and parcel of its meaning and symbolism. This aspect of its composition and intention has not yet been submitted to thorough theological-critical investigation and scrutiny. Stepping into the gap, this article traces the religious intention and intonation of the Monument. The first part of the article entails the history of the Moerdyk design, based on antique Egyptian religious architecture. Then a discussion of the way in which the architect blended his (Egyptian) design with the religious spirituality and nationalism of the Afrikaner is presented. The last section deals with the altar text in the heart of the building: 'We for thee, South Africa'. This secular text constitutes the religious statement of the memorial. Care should therefore be taken to embed the symbolism and meaning of the building in the Christian faith or the so-called Calvinism of the Afrikaner. The engagement with the Monument's religious statement revealed a sacrificed religion trapped in a still remarkable commemorative building.

\section{Introduction}

Erected on a hill to the southwest of Pretoria, the Voortrekker Monument, one of South Africa's most remarkable commemorative buildings, was designed to make a territorial, historical, cultural and religious statement (Delmont 1992:6; Emden 2013:326-327, 334; Moerdyk 1955:35; Steenkamp 2006:250). ${ }^{1}$ When a first ever model of the envisaged Monument went on display at the 1936 Empire Exhibition in Johannesburg, architect Gerard Moerdyk (1890-1958), Associate of the Royal Institute of British Architects, in his explication of the design, confirmed that the fundamental idea of the building was entrenched in religion. The mere stature of the Monument was framed to denote a spiritual and sacred association. It is a 'beautiful shrine', he said, placed within the spacious wall of a laager of wagons (The Star, 09 September, 1936a:n.p.). 'In the upper dome will be an opening for a shaft of light to filter in and illuminate a sarcophagus of Retief and his men', The Star reported on 09 September 1936 (The Star, 09 September, 1936a:n.p.).

Moerdyk so far did not expound on what this exactly entailed. Whenever, though, in coming years, he explained the meaning and symbolism of the Monument, the religious taxonomy that inspired the form of the building always received prominent accentuation. He linked this aspect in the formation of the design inextricably to the soul of the building and its message. The architectural ideas that generated the building were thus infiltrated by a religious extrapolation.

This contribution engages the religious statement which this imposing building epitomised. It thus labours to map out the predominant religious idea or concept, according to the architect, that inspired and shaped the structure. As respected authority, the architect's thoughts and intentions in this regard should be given preference and are indeed decisive in the appraisal of the religious trajectories and intonation he allowed for in designing the Monument. A leading question therefore is the following: what was at the heart of this temple, the elevating religious idea that shaped the revered Voortrekker Monument, and in which the genesis of the Moerdyk design is seated? The question is answered from a corpus of contemporary primary sources, of which the collection of Moerdyk Papers in the Merensky Library at the University of Pretoria, as well as the private collections of E.G. Jansen and J.I. Lombaard in the Archive for Contemporary Affairs at the University of the Free State, forms a pivotal part. The author is responsible for all translations of texts. The author does not endorse offensive language used by original sources.

1.'Voortrekkers' refers to the group of white people who, in an organised migration, left the Cape Colony during the years $1834-1838$ to establish themselves in the interior regions. 


\section{Moerdyk on memorials}

When the movement to erect a Voortrekker Monument was formally organised and gained momentum in the early 1930s, it was clear that Moerdyk's proposal for such a memorial would be considered. He was a protuberant public figure, a leader in the Afrikaner community, a member of the South African Academy for Science and Art and would be elected in October 1935 as the chairperson of the Council of the University of Pretoria, a position he held until 1942 (Artefacts n.d.). In addition, he already had designed a national monument to recall the fate and suffering of women and children in concentration camps during the Anglo-Boer War (1899-1902).

At the occasion of the induction of the Women's Memorial, erected in the cemetery of the concentration camp in Klerksdorp, Moerdyk elucidated the national value of a memorial. As an architect of the memorial, he was invited to conduct its inauguration during an exceptional Dingaansdagviering [Dingane's Day celebration] on 16 December 1920. His address was published in the February edition of Die Banier (Moerdijk 1921:164-165), the journal published by the 1917-incepted Afrikaanse Studentebond (Beukus 1933:37).

For Moerdyk, a memorial or monument should be the manifestation of 'the own' of the history of the Afrikaner. A pure creation in all respects divested of all that is foreign (Moerdijk 1921:165). The purpose of a memorial is 'to keep our history alive: when we look at it, we need to experience the event again'. It is no longer tied to the events then and there, 'but to here and now. On the history, we build our future' (Moerdijk 1921:165). ${ }^{2}$ 'With all the beautiful things we hear on Dingane's Day about ourselves and our nation', he observed, '... we still have to learn to build memorials' (Moerdijk 1921:164). ${ }^{3}$ The 'forged little angels from Italy, pressed doves and flowers from Manchester ${ }^{4}$ are striking evidence, he maintained, that what had been erected in South Africa was obviously foreign to the country. At this point, he asked:

Is this the spirit of the sturdy Voortrekkers, who were the first to see the mountains and plains of South Africa and subjected the wilderness - a soulless little angel from Carrara? No! We consist of stronger fabric. Take a rough piece of granite and write an inscription in unprocessed letters, but do it yourself as a nation, and it will reflect us purer than the imported angels. (Moerdyk 1921:164) $)^{5}$

2.Die doel van "n gedenkteken is om ons geskiedenis lewendig te hou, as ons daarnaar kijk moet ons weer die gebeurtenis deurleef. Dan is dit nie meer dan en daar nie, maar hier en nou. Op die verlede bou ons ons toekoms (Moerdijk 1921:165).

3.'Bij al die mooi wat ons op Dingaansdag hoor oor onsself en ons nasie ... (moet) ... ons nog ... leer om gedenktekens te bou' (Moerdijk 1921:164).

4..... nagemaakte engeltjies uit Italië, geperste duifies en blommetjies uit Manchester (Moerdijk 1921:164).

5.Is dit die gees van die stoere voortrekkers, wat die eerste was om die berge en vlaktes van Suidafrika te sien en wat die wildernis onderwerp het? - 'n siellose engeltjie van Carrara? Nee! Ons bestaat uit sterker stof. Vat 'n ruwe klomp graniet en skrijf ' $n$ opskrif daarop in onbewerkte letters, maar doet dit self as nasie, en dit sal ons suiwerder weergee as die ingevoerde engeltjies (Moerdijk 1921:164).
Did he apply his views to the design of the Women's Monument? Made up of finely finished granite, his design is, however, deliberately fashioned to the classical Greek monumental ideal, to which he enthusiastically devoted the first part of his speech. Unlike the Roman Empire, which has disappeared in history, the temples of the Greeks endured, he informed the audience, 'and inspired all, viewing them' (Moerdijk 1921:164). ${ }^{6}$ His Women's Memorial accordingly entailed a white middle piece, placed on a grey pedestal. White, Moerdyk explained, is the symbol of the purity and innocence of the woman. The middle piece consists of four columns, connected with an arch. 'In architecture the arch represents masculine strength, while the delicate column embodies the female' (Moerdijk 1921:165). Therefore, he indicated, four columns were placed at the corners, because the woman had carried the brunt of the Anglo-Boer War. Together with the male form, they support a little 'temple of love'. Eventually, Moerdyk remarked, he would like to see the figure of a child placed in the temple, as a symbol of the descendants for whom the sacrifice was made (Moerdijk 1921:165). ${ }^{7}$ From the grey pedestal of the monument, he concluded, a fountain discharges itself in a pond, 'to denote that we can restore the spirit by sojourning in the past, in order to receive anew courage and strength for the future' (Moerdijk 1921:165). ${ }^{8}$

Despite the emphasis on the 'own' in history, and the appeal for its consequential embodiment in indigenous memorials, Moerdyk's Women's Monument clearly resembles the universality and perpetuity of Greek architecture. He knowingly incorporated the fundamental religious nature (a 'temple of love') inherent to Greek architecture. His admiration for the Greek architecture should be traced to the classical embroidered education he received at the Architectural Association in London between 1910 and 1912. In 1912, he also attended the British School of Archaeology in Rome, before returning to South Africa (Artefacts n.d.). His initial exposure and access to the world of architecture had thus been decisively influenced by an orientation to the classical, in any case, as it was interpreted by the British Empire, at the time at its peak. This is confirmed by a number of Moerdyk articles for the Journal of the Association of Transvaal Architects during 1917, his book Kerkgeboue vir Suidafrika (Moerdijk 1918), the Klerksdorp Women's Memorial as well as his later publication Die geskiedenis van boukuns (Moerdyk 1935). Characteristic of Moerdyk's work is a typical conceptualisation related to ancient and classical architecture. A range of public buildings and churches still testify to this style (Artefacts n.d.).

Despite the classical character of his work, Moerdyk, as a prominent architect, tirelessly promoted the development of

6.... blij bestaan en besiel 'n ieder wat daarnaar kijk (Moerdijk 1921:164).

7.Die wit middelstuk, geplaas op 'n grouer onderdeel, is die sinnebeeld van die reinheid en onskuld van die vrou. In die boukuns stel die boog die manlike krag voor en die tere kolom die vrou. Darom set ek hier die vier kolomme op die hoeke omdat die vrou kolom die vrou. Daarom set ek hier die vier kolomme op die hoeke, omdat die vrou, soos die geval was die meeste moes uitstaan. Te saam met die manlike vorm dra hulle die tempeltjie van die liefde, waar ek graag later die beeld van ' $n$ kind in wil sien, as
simbool van die nageslag waar die opoffering voor gemaak is (Moerdijk 1921:165).

8.Ek laat ' $n$ fontein ontspring uit die monument om te bedui dat ons die gees kan lawe by die verlede en nuwe moed en krag kan krij vir die toekoms (Moerdijk 1921:165). 
a typical South African architectural style that should have its foundation, when explicating his ideas to the students of University of Pretoria in 1934, in the character, aspirations, heritage and history of the (Afrikaner) nation, and thus postulates suitability, durability and effectiveness of the 'Afrikaans spirit'. 'We hope for an Afrikaans architecture', he stated (Moerdyk 1934:19-21; see also Die Volkstem, 04 Julie 1929:n.p.; Die Volkstem, 02 Oktober, 1930:n.p.; Delmont 1992:4; Moerdyk 1938a:1-2). The movement to plan and manage the construction of an appropriate Voortrekker memorial offered the perfect opportunity to give physical form and expression to this endeavour. Moerdyk would participate, and was indeed asked to do so.

Did he utilise the favourable moment to design a monument that would embody the typical of the Afrikaner, which would capture the 'Afrikaans spirit', in terms of 'a pure creation, in all respects divested of all that is foreign'? Would the monument be shaped to accommodate the indigenous Christian religious orientation and spirituality of the Afrikaner? In the next section, the attention thus shifts to Moerdyk's proposed designs for a monument.

\section{Moerdyk's designs of a Voortrekker Monument}

The Central Voortrekker People's Monument Committee (henceforth Central Committee), established in 1931 (Anonymous 1931:1), guided the planning and erection of this national project (Jansen 1949:37-41). Substantially financed by a sympathetic South African government since 1935, ${ }^{9}$ a sub-committee (the 'Form Committee') was appointed in January 1936 and assigned to invite all interested parties to submit designs and proposals for the envisaged monument. ${ }^{10}$ The Form Committee was also required to serve the Central Committee with a final recommendation. After considering all submissions received, the Form Committee, at its meeting on 06 April 1936, opted for Gerhard Moerdyk's design, provided that the Stellenbosch Pienaar-Bouman proposal of a laager of wagons be incorporated. ${ }^{11}$ The Central Committee adopted the recommendation on the next day, also meeting in the Speaker's Chambers, Parliament Buildings, Cape Town. ${ }^{12}$ At this meeting (on 07 April 1936), the Pretoria-based Moerdyk was - 'on invitation' according to the minutes - present and appointed as architect. ${ }^{13}$

The core of his design is a granite mausoleum that includes (if so desired) a sarcophagus in which the bones of Retief and those who died with him in February 1838 at the hand of Dingane could be reinterred. ${ }^{14}$ He thus conceptualised his

9.PV 125 2/2/1/1/1: Letter 04 October 1935 Minister of Internal Affairs to Jansen; PV 125 1/2/2/1/1: Minutes Central People's Voortrekker Monument Committee (henceforth CPVMC) 02 November 1935; Jansen 1949:37-41.

10.PV 125 1/2/2/1/1: Minutes CPVMC 25 January 1936.

11.PV 94 1/74/10/1: Minutes Form Committee 06 April 1936; PV 125 1/2/2/1/1 Minutes CPVMC 07 April 1936

12.PV 125 2/2/1/1/1: Agenda CPVMC 12 March 1936.

13.PV 125 1/2/2/1/1: Minutes CPVMC 07 April 1936

14.PV 125 1/2/2/1/1: Minutes CPVMC 07 April 1936 design in terms of a mausoleum and sarcophagus. These were obviously key features peculiar to the ancient (Egypt and Persia) and classical (Greek and Romanian) architecture, and, in particular, associated with temples and religious comportment. He also affirmed that the laager of wagons could be combined with his blueprint. It is this joint design that went on display at the Empire Exhibition in Johannesburg later that year.

This was, however, not the first time that Moerdyk had the opportunity to discuss a design of the proposed monument with the Central Committee. It was also not his first design. Four years earlier, at its meeting on 14 April 1932, he was welcomed by the Central Committee with the view of informing the members about his sketch of the envisaged monument. ${ }^{15}$ The sources do not explain why Moerdyk was invited to explain his design. In his 1932 design, religious trajectories were hidden that surfaced in his second (1936) proposal.

In 1932, Moerdyk assumed 'when he drafted the sketch'16 that the monument would be erected at Blood River (better known as Ncome River), that is, at the place where the actual battle took place in northern rural Kwazulu-Natal on 16 December 1838. It must be massive, yet simple, to procreate the characteristics of the Voortrekkers, he said. This assumption has determined the shape of his design. Because the monument should be typical of Africa, it contains constituents of the Egyptian pyramid as well as the Zimbabwean ruins. The design, he pointed out, allows for two spacious halls, separated by a causeway. On one side, it is a mausoleum, which will contain the bones of Voortrekkers. On the other side, a museum is accommodated. On the walls, scenes from the history of the Great Trek would be presented in bas-relief at human height. The causeway in the middle is a symbolic representation of the passage that the white civilisation opened through the 'black savage populations ${ }^{\prime 17}$ into the interior. During festival days, he exclaimed, a pot of peck and oil will burn. Around the building, an amphitheatre with rostrum will create space for celebrations and speeches. ${ }^{18}$

A depiction of this initial design exists. In January 1936, the influential Pretoria paper, Die Vaderland, published a sketch of the envisaged monument that unmistakably delineates the 1932 minuted explanation. It has typical Egyptian temple features, in particular those of the temple of Horus at Edfu, a structure which Moerdyk discussed in his book on the history of architecture (Moerdyk 1935:36) and was thus well familiarised with it. Hence, it consisted of two trapezoidal pylons with walls sloping inwards, framing the prominent entrance. 'The design is in the nature of an Egyptian temple',

15.PV 125 1/2/2/1/1: Minutes CPVMC 14 April 1932.

16.PV 125 1/2/2/1/1: Minutes CPVMC 14 April 1932

17.This offensive language is used by the original source and is not endorsed by the author.

18.PV 125 1/2/2/1/1: Minutes CPVMC 14 April 1932. 
the caption indicated, linking it the Luxor temple complex (instead of Edfu):

Inside is space for conservation of memorabilia from the Voortrek. There is a pulpit for festivities and between the two front pylons an urn in which will always burn a fire. On the front gables and next to them and beyond will be sixteen bas-reliefs, depicting different scenes from the Voortrek. (Die Vaderland 1936b:7; see also Britz 2018:271)

Duffey (2006:27) is of opinion that this design was made in collaboration with Moerdyk's long-time friend, sculptor Anton van Wouw (1862-1945). Van Wouw, as a matter of fact, invited the Central Committee in 1933 to view a bas-relief of Piet Retief leaving the Cape Colony, which he designed on own initiative. ${ }^{19}$ When interviewed in this regard, Van Wouw envisioned a majestic memorial, huge, heavy and massive, situated on top of a hill where it will capture the visitor's attention instantly. It should be an interpretation of the unwavering character of the Voortrekker, conjoining with the environment. He said:

\begin{abstract}
... My idea would be two colossal obelisks, cut short and say 85 feet high, connected by a centerpiece above stairs, like the seats in a theater. The huge surfaces of the square needles must evoke the endless plains. They should remain undecorated, except for a panel each on the one side, of Retief and on the other side, of Andries Pretorius. Each must contain a room of say 40 by 60 feet. Inside should be a sarcophagus with the bones of Voortrekkers and around on the walls incidents from history in bas-relief. On the stairs and against the slope of the hill, the people could meet for festivities. (Die Vaderland, 28 Augustus 1933a:5)20
\end{abstract}

There are similarities between the descriptions of Van Wouw and Moerdyk, and there are differences. Neither Moerdyk nor Van Wouw acknowledged any cooperation. According to a report in Die Burger on 02 September 1933, Van Wouw requested Moerdyk to make such a design (Die Burger, 02 September 1933b:11). For the purposes of this article, the design itself is of more importance. It opens a perspective on the envisioned Voortrekker memorial, which preceded the final accepted Moerdyk design.

The 1932 minutes recorded that Moerdyk related his design to the Egyptian pyramids and the Zimbabwe ruins. The 1936 published drawing clearly resembles the Edfu temple in Egypt, and not a pyramid (see Kleiner en Mamiya 2005:75). However, it is generally agreed that pyramids were burial monuments, hence the association with a sarcophagus and with the resurrection of the spirit of life force of the Pharaohs. Moerdyk probably referred to pyramids in general, without committing to a particular pyramidal design (see Britz 2018:271-273). The famous Egyptian structures 'typical of Africa' (Moerdyk does not associate Egypt with the

\section{PV 125 1/2/2/1/1: Minutes CPVMMC 05 August 1933}

20.My idee sou wees twee massiewe naalde, kortgekap en sê 85 voet hoog verbind deur' $n$ middelstuk bokant trappe soos sitplekke in 'n teater. Die groot vlakke van die vierkantige naalde moet lat dink a n die vierkantige naalde moet laat dink aan die oneindige vlakte. Hulle moe onversierd bly behalwe vir ' $n$ paneel elk, eenkant van Retief en anderkant van Andries Pretorius. Elkeen moet bevat ' $n$ kamer van se 40 by 60 voet. Daarbinne moet staan ' $n$ sarkofaag met die bene van Voortrekkers en om die mure in basreliëf voorvalle uit die geskiedenis. Op die trappe en teen die hang van die randjie sal die volk by feestelikhede kan vergader (Die Vaderland, 28 Augustus 1933a:5).
Mediterranean countries, nor the civilisations of the ancient East) embodied an unblemished religious character.

The option for an Egyptian temple and the directional reference to the pyramid are significant for what he would capture in the grandiose national monument. Other than 15 years earlier, the conceptual location for this monument was not the classical Greek architecture, but it was situated within the ambit of religious structures typical of ancient Egypt. This ancient (and religious) setting forms the platform that carried his design, and conveyed its symbolic and religious meaning and scope associated with death, funeral, sacrifice and resurrection or spiritual re-awakening.

The second Moerdyk design was accepted by the Central Committee and went on exhibition in Johannesburg. It seems to vary quite radically from the first design. It does not consist of two massive pylons, but forms an inclusive and undivided unity. Elsewhere, this author (Britz 2018:276) has shown that if the two designs are mapped over one another, the intertwining is too conspicuous to ignore. It is clear that the original design, based on the Egyptian temple structure (Edfu), was incorporated by Moerdyk in the final Voortrekker Monument proposal. The author is convinced that Moerdyk's education had profoundly influenced him in terms of the use of ancient and classic building styles in his architectural work, and that his two related designs for the Voortrekker Monument are no exceptions. The design of the Voortrekker Monument was indeed inspired by the temple architecture of ancient Egypt, identified by the architect as a mausoleum, a shrine that is host to a sarcophagus containing the bones of Voortrekker heroes. Undoubtedly, it is a religious building, a sanctuary that, as a site of memory, was intended to serve the purposes of commemoration. The ancient Egyptian temples and religious associations and symbolism formed the envelopment in which the religious statement of the building would be enclosed.

\section{The transformation in meaning and symbolism}

The model that went on show in Johannesburg in September 1936 revealed to the public eye the layout and form of the proposed Voortrekker Monument. The design provoked immediate criticism. In the public press, sharp opinions were expressed. The design was too 'eastern', and therefore 'onafrikaans' and thus could not be associated with Afrikaner tradition and historical interpretation. As a Fremdkörper in this tradition, it was just not fit for purpose. In early 1937, the Central Committee responded and defended its selection of the Moerdyk design. An in-depth analysis of this response (Britz 2018:278-280) disclosed that the Central Committee, in collaboration with the architect, now avoided explicating the symbolism and meaning of the building in terms of its Egyptian-inspired design. Instead, the emphasis shifted to two protruding and interrelated trajectories of explanation. Firstly, the mere format and structure of the building was interpreted to depict a portrayal of true Afrikaner nationalism 
and historical interpretation. Secondly, the building was also attuned to the spirituality and religious inkling of the Afrikaner people. It was made clear: in the 1936 design, not only the Afrikaner's historical view is given a place of honour, but a building was also shaped in which her or his religious spirituality would also resonate.

With this explicit interpretation, the nationalisation of both the Monument and the events it portrayed as a site of memory was incepted. At the inauguration of the building, it even went farther: the Monument was then depicted as a symbol and mandate of the Afrikaners proprietary right of ownership of South Africa. It now served ideological purposes (see Britz 2018:284). This alteration in the explanation of the symbolism and meaning of the Monument represents a departure from the original purpose and intention of the Central Committee. It also compromised the intentions of the government in its support of the project, which had an underlying motive to further the appeasement of Afrikaans and English speaking white citizens..$^{21}$ The Monument and its symbolism have now become the exclusive servant of the Afrikaner and her or his religion.

In the future, Moerdyk would stick to these two lines when reflecting on the meaning and symbolism of his design. Both were to be accommodated in the design of his building: the exposition of a significant historical event that was to be connected with a contemporary sense of religiousness or spirituality. The Monument had to offer a sense of belonging to both. It should subtly engage the Afrikaner visitors in reverence and benediction, setting up an affective relationship between them and the space of commemoration (see Steenkamp 2006:251). The Afrikaner who crossed the threshold of the Monument, Moerdyk pictured the purpose of the building, should leave a 'better Afrikaner' than the one who entered (Moerdyk 1949a:7). This reminds of his 1920 statement: 'By sojourning in the past, it should restore the spirit in order to receive anew courage and strength for the future' (Moerdijk 1921:165).

As noted, the religion and spirituality practiced in association with Egyptian temples were shaped by beliefs about death, burials, sacrifices, resurrection and re-awakening. In line with this, the majestic physical structure and the voluminous lines of the proposed Voortrekker Monument and its atmosphere would evoke and suit the purpose of the kind of Afrikaner spirituality which was linked by Moerdyk to death, sacrifice, burial and re-awakening in commemorating the Voortrekkers (Argitek 1938:32; Moerdyk n.d.:2). However, this spiritual intention had to be utterly reconciled with the generally accepted and common Christian religious ethos of the Afrikaner. How was this effected by Moerdyk?

\section{An altar in the heart of the shrine}

It is not without significance when Moerdyk observed in 1938 that, 'since our people is par excellence a religious Correspondence Letter 26 July 1938 General Hertzog to Advocate E.G. Jansen. people', the Voortrekker Monument is, in terms of the Vow before the Battle of Blood River (16 December 1838), consequently 'a temple, secluded from the hustle and bustle of daily life and bold in structure, as was the Voortrekker ancestors' (Argitek 1938:31). As a building, the Voortrekker Monument must therefore attempt to replicate 'the whole spirituality, or mood, state of mind, disposition and history of the Afrikaner'. 'The foundation', wrote Moerdyk in the Kwartaalblad van die Afrikaans-Duitse Kultuur-Unie, in 1938, 'is religious: it is a temple placed within a spacious wall of laager wagons' (Moerdyk 1938b:5).

To conceive a worthy monument was a difficult task, Moerdyk asserted when he broached the subject of the genesis and formation of the structure. To guide him in this regard, he said, he postulated a question: Assuming that the Voortekkers wished to erect a monument, where would they have sought inspiration for such a venture? He presumed that they would have consulted the Christian Bible, probing to find circumstances similar to their own, and then act accordingly. Similar circumstances, according to the architect, would be found in the biblical story of the 'exodus of Abraham' from Ur of the Chaldeans. That patriarch left his home country to set up a new state. In his doings, 'we often read these words: He builds an altar there' (Moerdyk 1949c:44). Moerdyk thus resolves: that is what the Voortrekkers would do. They would build an altar. They would have made their monument a religious one, based on a well-known biblical story.

He readily concedes that 'the altar of today is different from that of Abraham's time', but, he notes, the underpinning thought or idea remains the same. Through the ages and among all nations, the altar exemplifies or embodies sacrifice and dedication (Moerdyk 1949c:44). This is the tangent point in which the Egyptian temple trajectory finds common ground with the Afrikaner's spirituality and religioushistorical mentality. Moerdyk elucidates: 'This is the symbol of sacrifice, and in the monument the altar takes the form of a sarcophagus for Piet Retief and his men slaughtered at Dingaanstat' (Moerdyk 1949a:3).22 They made the ultimate sacrifice for South Africa with their lives. It is around this idea of an altar that the building would take its shape (Moerdyk 1949b:4). From this centre, the granite building emerged in widening circles (Moerdyk 1949b:4), employing geometric order and spatial proportions (Steenkamp 2008:92-136).

The (Abraham) altar-sarcophagus is located deep in the heart of the building. It is the concentric point in which the major trajectories converge to mushroom in the majesty of the Monument high on a hill near Pretoria. In this way, the architect brought together religious motives, the magnificence of the building and a nationalist interpretation of history. The trajectory related to the Christian religion and spirituality of the Afrikaner as embodied in the (transubstantiated) sarcophagus-altar is, however, deep-seated in the initial

22.It should be noted that the 'altar' never was a sarcophagus. It was indeed a cenotaph. No reburial ever took place. The 1955 Official Guide changed it to cenotaph, thus correctly (Board 1955:34). 
(non-Christian) trajectory discussed, namely the ancient archetypes of the Egyptian religious architecture created by religious practices. This remarkable interlacement of religious traditions was made possible by the text chosen as inscription on the central altar of the building. Annually, on 16 December at noon, the penetrating sunray falling downwards from the upper domes of the building highlights these words. Undoubtedly, the main 'spiritual' feature of the building.

\section{A religious moment of significance: 16 December 1938}

Amidst hundreds of thousands of Afrikaners, the laying of the cornerstone on 16 December 1938 carried a distinctively religious, and in particular national, Christian character. It involved the full participation of the three main Afrikaans reformed churches. ${ }^{23}$ The Government, and therefore Prime Minister Hertzog, withdrew in impeccable style from the proceedings following a sordid public dispute, refusing to sing 'God Save the King' (the official anthem) at the intended official state ceremony. ${ }^{24}$ It was transformed to an Afrikaner cultural-religious event.

The laying of the cornerstone on 16 December 1938 was the culmination of a symbolic ox wagon trek across South Africa, organised by the Afrikaanse Taal-en Kultuurvereniging of the South African Railways and Harbours (Van Rensburg 1969:301-346; 1980:100-119). The Goods and Harbour Superintendent of the Mosselbaai Port, Henning Klopper, initiated and led the trek. This unexpectedly carried the Afrikaner nationalism to high expectations, while the ox wagon was lauded with iconic status. For the Afrikaner, the climax in Pretoria would be an experience not to be missed, either through personal attendance or through the radio broadcasting and the press.

The apparent religious charisma and prestige of the event correlated with the date 16 December, or rather, with the text that created that date in the collective memory of the Afrikaner in general, referred to as the Vow. This text determined the date of the laying of the cornerstone as well as that of the inauguration of the Monument on 16 December 1949.

The original content of the Vow lies in oblivion. It could be anticipated that the first uttering of the Vow comprised the outline and structure of the pledge the Pretorius commando participated in. It clearly relates to the Christian belief of the initiators, and is an expression of the faith of the commando. Contributing factors would be the intense awareness of consequences of the situation, either the final end, or the advance of a common future, or human fear, piety, devotion and faithful trust in God.

Historical research indicates that 16 December has been publicly - at first as a church service - commemorated since 23.PV 125 1/2/2/1/2: Minutes CPVMC 21 March 1938 and 31 May 1938.

24.PV 94 1/13/4/10: Correspondence, Letter 26 July 1938 General Hertzog to Advocate E.G. Jansen.
1864: initially locally in the vicinity of the battlefield and later in particular in the northern provinces, until it became a public holiday in the 20th century national calendar (see Baily 2003; Prior 1999:85-88; Van Jaarsveld 1980:8-59). In its adapted form, as text-critical studies show, the text later seized and determined a historical interpretation, created a theological impact on the view of history and resulted in the proliferation of an exclusive life orientation ('apartheid'). In the celebration of the day, and the nationalisation thereof, the emphasis is not only on the outcomes of the pledge, but also on the Blood River victory and the exclusive significance of that victory.

The text of the Vow used in 1938 reads as follows:

My brothers and fellow countrymen,

Here we stand presently on a moment before a holy God of heaven and earth, to make a promise to him that:

- if he, in terms of his protection, be with us and give our enemy into our hands, that we will conquer him

that we (then):

- shall keep this day and date every year as an annual anniversary and a day of thanksgiving like a Sabbath to his glory

- and that we shall erect a temple to his honour wherever it should please him,

- and that we also will tell our children that they should share in that with us in memory also for our future generations.

For the honour of his name will be glorified by giving him the fame and honour of our victory. (Author's own translation)

The taking of the Vow occupied a central position in the programme for 16 December 1938 (Sentrale VoortrekkerEeufeeskomitee 1938:25, 28). It was not read during the early Worship of the Vow, conducted by Dutch Reformed Minister Rev. J.M. Louw, at 09:00. It was part of the conclusion of the main worship service of the day, which commenced at 11:00 and incorporated the solemn laying of the cornerstone. Dr J.D. Kestell (Dutch Reformed Church) led the first part of the service, followed by the sermon of the 'volksmanpredikant', ${ }^{25}$ J.D. du Toit (Reformed Church), ${ }^{26}$ the laying of the cornerstone, and an address by E.G. Jansen, the chairperson of the Central Committee since 1931. Following the announcement by Jansen that the cornerstone was laid, the crowd of more than 100000 people broke out in jubilation and spontaneously sang Die Stem ... (Die Vaderland, 17 Desember 1938b:1). The service was then concluded by Rev. J.J. Prinsloo (Hervormde Church), who, before the benediction by Rev. L.E. Brandt (Hervormde $\mathrm{Church}^{27}$ ), read the Vow. The proceedings were interspersed with choral singing (Sentrale Voortrekker-Eeufeeskomitee 1938:25, 28). 25.'Volksman-predikant' as a concept indicates that Du Toit was recognised by the
Afrikaner people as 'their' minister of religion in the first place. This was generally
given priority above the fact that he was in particular an ordained minister of the
Reformed Church.

26.PV 94 1/13/4/2: Minutes Central Centenary Committee 31 May 1938.

27.The official English for 'Hervormde Kerk' is Netherdutch Reformed Church of Africa. 
The solemn reading of the Vow composed a sacred moment. The proposed programme indicated that it should be taken with uncovered head, and by the raising of the right hand, ${ }^{28}$ which was customary in many places (see Die Vaderland, 10 Desember 1938a:2). A great silence gripped the multitude as Prinsloo read the Vow (Die Vaderland, 17 Desember 1938b:1). It was a moment of significance (see Mostert 1940:780).

Mediated by the text of the Vow, those who took it anew - it was believed - came in the presence of God to plight themselves to the conditions and consequences of the Vow. Hence, the religious acts: the uncovering of the heads, the raising of hands and the silence. History came alive. A collective religious experience was the manifestation of a shared Afrikaner spirituality. The events referred to in the Vow were re-awakened and re-lived. It served the purpose of the memorial as envisioned by Moerdyk at the inauguration of the Women's Memorial in Klerksdorp op 16 December 1920 , that is, 'to keep our history alive: when we look at it, we need to experience the event again' (Moerdijk 1921:165). It is no longer, he observed, tied to the bygone and transient historical events but to the here and now: 'On the history we build our future' (Moerdijk 1921:165).

The laying of the cornerstone was the public deed by which the people usurped the Monument in terms of a communal ownership. A sense of belonging was born. Undoubtedly, this historical-theological and religious text and its exclusive intention and message dominated at both the 1938 laying of the cornerstone (Sentrale Voortrekker-Eeufeeskomitee 1938:25) and dedication (Voortrekker monument-Inwydingskomitee 1949:17) of the Monument (1949). ${ }^{29}$ Its sustaining theology was and is, however, foreign to the interpretation of the reformed confessions, intrinsically non-Calvinistic, and never officially questioned by any of the Afrikaans reformed churches. This religious text created and shaped a national and Christian site of memory.

\section{The central text of the Monument}

On 16 December each year, at noon, the sun, however, does not penetrate the aperture in the upper dome of the Monument and travels through three stories to enlighten on the altar the text born in the week preceding the decisive Battle of Blood River, but it hits a contemporary text, taken

28. In all draft programmes for the 16 December, the renewal or taking of the Vow was stipulated to be conducted by the raising of the right hand (see PV 125 1/2/1/1/1 stipulated to be conducted by the raising of the right hand (see PV 125 1/2/1/1/1: Agenda Meeting Centenary Committee 13 August 1938; PV 380 1/13/4/22: Central
Centenary Committee: Programmes Circular 1: 17 May 1938). Attachment 2 contains the three main services and stipulates: 'Repetition of the Vow with the raising of the right hand, followed by the benediction'. (My translation: D.B.) The same file holds the prospective proof sheets of the programme. These only specify: 'Reading of the Voortrekker Vow'.

29.Moerdyk (1949d:56) used the text of the Vow, as given by Manfred Nathan: 'My brethren and fellow countrymen, at this moment we stand before the holy God of heaven and earth, to make a promise, if $\mathrm{He}$ will be with us and protect us, and deliver the enemy into our hands that we may triumph over him, that we shal observe the day and the date as an anniversary in each year and a day of thanksgiving like a Sabbath, in His honor; and that we shall enjoin our children that they must take part with us in this, of a remembrance even for our posterity; and if any one sees a difficulty in this, let him return from this place. For the honor on His Name shall be joyfully exalted, and to $\mathrm{Him}$ the fame and the honor of the victory must be given' (1937:252). Moerdyk remarkably did not include the different must be given' (1937:252). Moerdyk remarkably did not include the
Afrikaans text of the Vow used at this occasion (see Moerdyk 1949c:54). from C.J. Langenhoven's 1918 poem Die Stem. ${ }^{30}$ As an extremely popular song among Afrikaners, Die Stem insisted on national recognition in the 1930s. The religious concepts and assumptions embodied in the song are scaffolded by historical assumptions and interpretation, which give it a nationalised Christian image. In this song was carved out a people's or folk (Christian) theology that was thus carried across the breadth and length of South Africa.

The altar of sacrifice in the heart of the building bears an inscription: Ons vir jou Suid-Afrika [We for thee South Africa]. It is the central text of the Monument. It concludes the first verse of Die Stem. ${ }^{31}$ A literal translation of the end of this verse is:
We will answer to your calling,
We will offer what you ask,
We will live, we will die,
We for thee South Africa.

It is the last line that catches the brilliance of the sun, shining into the Afrikaner's temple from its highest point. It is a text that the Voortrekkers did not know, and it is essentially foreign to the kind of reformed faith that was practiced in South Africa among the Afrikaners. After all, the well-known Heidelberg Catechism emphasises that the believer, in life and in death, does not belong to herself or himself (neither to her or his people nor to a fatherland), but to Christ. That is their only comfort. Die Stem's 'we will live, we will die, we for thee South Africa' in actual fact contradicts the Catechism. It demands the unconditional sacrifice to the country. It is indeed moulded in language of self-sacrifice and surrender to the cause of the people and the land. Was this emphasis on sacrifice the noble attraction for Afrikaner spirituality to devote itself to a cause? To find sense and meaning in life and existence? It is in any case something that the text of the Vow would not be able to do, and hence its absence on the altar.

In dealing with the religious intention of the Monument, the remarkable way in which the historical text that created and shaped religious and historical commemoration at a symbolic date was substituted by a popular contemporary text thus surfaces. This is no coincidence. It is the prerequisite for the reception of the Monument as a fundamental part of the Afrikaners' religious spirituality. The language of sacrifice typical of Die Stem synchronises with a temple, a sarcophagus, a mausoleum and is in harmony with all the other important religious aspects of the Moerdyk design of the Monument. The pious 1838 prayer of Cilliers, underpinning the text of the Vow, simply does not fit, and would not have the effect of Die Stem on the altar in the heart of the Monument. The esprit de core of this spirituality is symbolised contemporary Christian nationalism, or rather of a nationalised cultural Christianity.

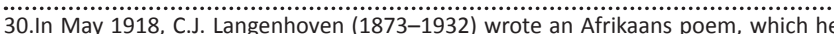
entitled 'Die Stem'. It was set to music by the Rev. M.L. de Villiers in 1921. It was widely used by the South African Broadcasting Corporation in the 1920 s, which widely used by the South African Broadcasting Corporation in the 1920s, which played it at the close of daily broadcasts, along with 'God Save the King'. It was sung publicly for the first time on 31 May 1928. It was sung in English as well as Afrikaans did not cease to have official status until 1957 .

31.'Die Stem' is officially entitled 'The Call' (of South Africa), although 'stem' literally means 'voice'. 


\section{Conclusion: A religion sacrificed, trapped in the Monument}

In recent times, the reflection and historical images that encapsulated the central idea of the building became publicly suspicious (Autry 2012:146-164; Delmont 1992:5; Mare 2007:36-48; Marschall 2006:165-185). In 2006, Alta Steenkamp (2006) summarised the outcomes of the contemporary critique as follows:

The Voortrekker Monument is aesthetically suspect because it is tied to an architectural language that equates order with the 'civilised'; politically suspect because it is seen as a representative of apartheid totalitarianism; socially suspect because it is seen as a privileged mode of expression that excluded the 'other'; and ethically suspect in its size and attempt to overwhelm the visitor by its grandiosity. (p. 254)

At the outset, assumed to be one of a kind, the building's uniqueness and African ingenuity was highly regarded. Contemporary taxation rather emphasises, as part of and deeply influenced by the European tradition of monumentalising, its derivative design (see Emden 2013:234; Steenkamp 2011:79-89), which makes the building one among others. Recently, Ariane Janse van Rensburg epitomised the structure as a 'formal, massive art-deco granite icon of Afrikaner Nationalism' (Janse van Rensburg 2009:34).

However, within the context of the questioning of the Monument and the statement it makes, it is too easily accepted that the religious aspect is related to the Afrikaners' Calvinism and Christian beliefs (Autry 2012:149; Crampton 2001:234; Janse van Rensburg 2009:38). The setting of the religious statement of the building, as indicated in the unfolding of the underlying argument of this article, is clearly seated in the ancient Egyptian temple and pyramid architecture. This is where the origin of the design is to be found. Its composition allowed for the accommodation of the spirituality and religion of the Afrikaner people. This was achieved by suggesting that the original idea that created and shaped the Monument was initiated by the wellknown story of the altar that Abram built, as recorded in Genesis 12. To do this, the architect generalised and adopted the biblical information to suit his purposes.

Moerdyk tied into the Abram story, but in utilising it, he ignored not only fundamental facts, but also the Christiantheological interpretation underpinning this biblical story. He dotted the i's and crossed the t's of this story more than once. In the biblical account, Abram (not Abraham) did not leave Ur to 'establish a new state' in the 'promised land'. Neither are the altars that Abram erected linked to any form of self-sacrifice. These were embedded in a religious ritual, in which God was thanked, within the broader trajectory of salvation from sin. In fact, the Bible forbids the sacrifice of humans. In later developments, certain animals were sacrificed as substitutes, which culminated, according to the Christian Bible, in the sacrifice of Christ Jesus on Calvary. Moreover, God never decreed Abram to multiply.
This is a mistake. The urge to make South Africa a white man's land cannot therefore be linked to this 'biblical' connotation.

Moerdyk also conveyed the idea of an altar to the assumption that through the ages and among all nations, the altar exemplifies or embodies sacrifice and suffering. His idea of an altar as sarcophagus is therefore not particularly biblical, although it is provided with biblical authority. His altar is of religious origin, but certainly not Christian. It actually excludes fundamental trajectories defining the Christian faith. The centre is the sacrifice of Retief and his party. Moerdyk therefore did not assign a different meaning to the biblical text: he actually departed from the core significance of the biblical text. The text was utilised as memory and association, but it was applied to serve the purposes of the architect. It is however a powerful link to the spirituality of the Afrikaner of the time: among the Afrikaners, the Bible, as God's Word, was publicly held in high regard.

The ultimate reception of the Monument and what it embodied was carried by Die Stem, a gripping interpretation of and association with mutual distress and suffering, as a sacrifice for the land and platform of inspiration to face the future.

Fundamental criticism has been raised against the equalisation of the religious statement of the Monument with the Christian faith. This monument temple as a deliberate site of memory incorporated the Christian faith and became employed by a national will that is led and legitimised by a political party (Crampton 2001:224) which justified apartheid Christian theologically. In this line, the Monument, as interpreted and explicated by its architect, finds itself. This religion became an ideology and the ideology became a religion. An unbelievable belief system was Christianised.

The ultimate question thus concerns the issue of the religious integrity of the Christian faith, as it was undeniably elevated to be the mouthpiece in the origin, design, form and reception of the Voortrekker Monument. It is a question that goes beyond the monumentalisation of faith. Theoretically, the monumentalisation of religion is interested in the extent to which religion retains its quintessence and nature when it is deliberately embodied in a memorial building. And what are the consequences of this 'monumentalised' version for the practice of the religion? A few years ago, Johan Cilliers outlined the history and religious meaning of the Voortrekker Monument as a case in point, discussing aesthetic-theological perspectives on the monumentalisation of religion. His interesting article is limited to reflection and existing scholarship (Cilliers 2015:4-6), while the primary sources in this regard remained untouched in the archives. Moreover, as the argument of this research unfolded, a concept of God and the spirituality associated with the Monument unlocked a much more dynamic than static appreciation of religion.

The engagement with the Monument's religious statement revealed a sacrificed religion trapped in a still remarkable 
commemorative building. The real story of its intention as embodied in its origin, composition and reception reminds of yet another biblical expression: 'It is the hands of Esau, but the voice of Jacob'.

\section{Acknowledgements Competing interests}

The author declares that he has no financial or personal relationships that may have inappropriately influenced him in writing this article.

\section{References}

Anonymous, 1931, Volksmonumente Bespreek, n.p. (In PV 125 4/2/1/1/1: Artikels, c. 1938.)

Argitek, 1938, 'Die simboliek van die Voortrekkermonument', in Sentrale VoortrekkerEeufeeskomitee, Sentrale Voortrekker-Eeufees 1838-1938 Pretoria 14-16 Desember 1938, pp. 31-33, Die Afrikaanse Pers, Johannesburg.

Artefacts, n.d., Moerdyk, Gerard Leenert Pieter, viewed 16 August 2017, from http:// www.artefacts.co.za/main/Buildings/archframes.php?archid=1102

Autry, R.K., 2012, 'The monumental reconstruction of memory in South Africa: The Voortrekker Monument', Theory, Culture \& Society 29(6), 146-164. https://doi. org/10.1177/0263276412438596

Baily, A., 2003, 'Die Gelofte van 16 Desember 1938: Herdenking en betekenis daarvan 1838 tot 1910', MHCSc dissertation, Department of Cultural History, University of Pretoria, viewed 12 January 2018, from http://upetd.up.ac.za/thesis/available/ etd-07242003-161607/

Beukus, P., 1933, 'Die Afrikaanse Studentebond', Die Huisgenoot XVII[566], 27 Januarie, p. 37, 57.

Board of Control of the Voortrekker Monument, 1955, The Voortrekker Monumen Pretoria. Official guide, Board of Control of the Voortrekker Monument, Pretoria.

Britz, D., 2018, 'Wie het die ontwerp van die Voortrekkermonument geïnspireer: Farao of Abram?', Litnet 15(1), 266-296.

Cilliers, J., 2015, 'God in granite? Aesthetic-theological perspectives on the monumentalisation of religion', Scriptura 114(1), 1-13. https://doi.org/10.7833/ 114-0-1041

Crampton, A., 2001, 'The Voortrekker Monument, the birth of Apartheid, and beyond', Political Geography 20(2), 221-246. https://doi.org/10.1016/S0962-6298(00) 00062-7

Delmont, E., 1992, 'The Voortrekker Monument: Monolith to myth,' Myth Monuments Museums. New Premises? History Workshop, University of the Witwatersrand, 16-18 July, pp. 2-21.

Duffey, A.E., 2006, " $n$ Egte lugkasteel: Moerdijk, Van Wouw en die Voortrekkermonument', Suid-Afrikaanse Tydskrif vir Kultuurgeskiedenis 20(2), 22-41.

'Eie boustyl vir S.A. nodig', Die Volksblad, 02 Oktober, 1930, n.p.

Emden, C.J., 2013, 'Land, race, and citizenship: The political spaces of monumentalism in South Africa', Anglia 131(2-3), 314-353. https://doi.org/10.1515/anglia-2013-0039

'Eresuil vir ons helde ...', Die Vaderland, 28 Augustus, 1933a, p. 5.

'Form of Voortrekker memorial. A great shrine 130 feet high on a hilltop in 30 acres of land', The Star, 09 September, 1936a, n.p.

'Gelofte op Danskraal hernu,' Die Vaderland, 10 Desember 1938a, p. 2.

'Grootste plegtigheid in die geskiedenis van die Afrikanervolk', Die Vaderland, 17 Desember 1938b, pp. 1-2.

'Grootste ontwerp vir ons Voortrekkermonument,' Die Burger, 02 September, 1933b p. 11.

Jansen, E.G., 1949, 'The realization of an ideal', Voortrekker Monument Inauguration Committee, Inauguaration of the Voortrekker Monument. Offical Programme Pretoria, December 13 to 16, 1949, pp. 37-41, Voortrekkerpers, Johannesburg.

Janse van Rensburg, A., 2009, 'Comparing altars and agendas - using architecture to unite?', South African Journal of Art History 24(1), 33-49.

Kleiner, F.S. \& Mamiya, C.J., 2005, Gardner's art through the ages, Wadsworth Thompson, Belmont, CA.

Moerdyk, G., n.d., 'Die Voortrekker-Monument deur die argitek Gerhard Moerdyk ARIBA', unpublished article, Moerdyk Papers, Merensky Library, Special Collections, University of Pretoria, 1-3.

Moerdyk, G., 1949a, 'Die wording van die Voortrekkermonument', unpublished article, Moerdyk Papers, Merensky Library, Special Collections, University of Pretoria, 1-7.
Moerdyk, G., 1949b, 'Ontwerp en simboliek van die Voortrekkermonument' unpublished article, Moerdyk Papers, Merensky Library, Special Collections, University of Pretoria, 1-8.
Uniblis

Mare, E.A., 2007, 'Monumental complexity: Searching for the meaning of a selection of South African monuments', South African Journal of Art History 22(2), 36-48.

Marschall, S., 2006, 'Transforming the landscape of memory: The South African commemorative effort in international perspective', South African Historical Journal 55, 165-185. https://doi.org/10.1080/02582470609464936

Moerdijk, G., 1918, Kerkgeboue vir Suidafrika, n.p., Johannesburg.

Moerdijk, G., 1921, 'Die nasionale waarde van ' $n$ gedenkteken. Toespraak gehou by die onthulling van die Klerksdorpse Vrouemonument deur Gerard Moerdijk, ARIBA', Die Banier 2(2), 164-165.

Moerdyk, G., 1934, 'Ons hoop op 'n Afrikaanse boustyl', Castalia, Oktober, 19-21.

Moerdyk, G., 1935, Die geskiedenis van die boukuns, J.L. van Schaik, Pretoria.

Moerdyk, G., 1938a, 'Die Voortrekkermonument', Koers VI(3) Desember, 1-4.

Moerdyk, G., 1938b, 'Die Voortrekker-Monument', Die Kultuurskakel. Kwartaalblad van die Afrikaans-Duitse Kultuur-Unie. Mitteilungsblatt der DeutschenAfrikanischen Kulturgemeinschaft III(3/4), Desember, 5-6.

Moerdyk, G., 1949c, 'Die Voortrekkermonument', Voortrekkermonumentinwydingskomitee, Inwyding van die Voortrekkermonument. Amptelike program en gedenkboek Pretoria 13 tot 16 Desember 1949, pp. 43-55, Voortrekkerpers, en gedenkboek
Johannesburg.

Moerdyk, G., 1949d, 'The Voortrekker Monument', Voortrekker Monument Inauguration Committee, Inauguration of the Voortrekker Monument. Official Programme Pretoria, December 13-16, pp. 43-57, Voortrekkerpers, Johannesburg.

Moerdyk, G., 1955, The Voortrekker Monument Pretoria. Official guide. Compiled and published by the Board of Control of the Voortrekker Monument, n.p., Pretoria, pp. 33-38.

Mostert, D., 1940, Gedenkboek van die Ossewaens op die Pad van Suid-Afrika. Eeufees: 1938-1939, Kaapstad, Afrikaanse Taal- en Kultuurvereniging (SAS en H), Hartenbos.

Nathan, M., 1937, The Voortrekkers of South Africa. From the earliest times to the foundation of the republics, Gordon and Gotch, Ltd., London.

'Ons dooi staatsgeboue', Die Volkstem, 04 Julie, 1929, n.p.

Prior, M., 1999, The Bible and colonialism. A moral critique, Sheffield Academic Press, Sheffield.

PV 94 1/13/4/2: Sentrale Eeufeeskomitee Agendas en Notules, 1938.

PV 94 1/13/4/10: Korrespondensie Monumente-komitee, 1938.

PV 94 1/75/10/1: Vormkomitee notules, korrespondensie, ens., 1936.

PV 125 1/2/1/1/1: Agendas: Sentrale Volksmonumente-Komitee, 01 Sept. 1934-30 Nov. 1949.

PV 125 1/2/2/1/1: Notules van die Sentrale Volksmonumente-Komitee, $14 \mathrm{Apr}$ 1932-04 Nov. 1937.

PV 125 1/2/2/1/2: Notules van die Sentrale Volksmonumente-Komitee, 07 Februarie 1938-20 Desember 1938

PV 125 2/2/1/1/1: Korrespondensie Sentrale Volksmonumente-Komitee, 30 Augustus 1932-22 Desember 1937.

PV 125 4/2/1/1/1: Artikels, c. 1938.

PV 380 1/13/4/22: Sentrale Eeufeeskomitee: Programme.

Sentrale Voortrekker-Eeufeeskomitee, 1938, Sentrale Voortrekker-Eeufees 1838-1938 Pretoria 14-16 Desember 1938, Die Afrikaanse Pers, Johannesburg.

Steenkamp, A., 2006, 'Apartheid to democracy: Representation and politics in the Voortrekker Monument and Red Location Museum', Theory 10(3/4), 249-254. https://doi.org/10.1017/S1359135506000352

Steenkamp, A.C., 2008, Space, power and the body - The civil and uncivil as represented in the Voortrekker Monument and the native township model, Delft University of Technology, Delft.
Un

Steenkamp. A.C., 2011, 'Ambiguous associations: Monuments referred to in the design of the Voortrekker Monument', South African Journal of Art History 26(3), 79-89.

Van Jaarsveld, F.A., 1980, 'A historical mirror of Blood River', in Keane, H. \& König, A. (eds.), The meaning of history: Problems in the interpretation of history with possible reference to examples from South African history such as the Battle of Blood River, pp. 8-59, University of South Africa, Pretoria.

Van Rensburg, A.P.J., 1969, Op die voorpos. Die verhaal van die stigting, strewe en prestasies van die ATKV (SAS en H). Unpublished manuscript, Archive for Contemporary Affairs, University of the Free State, Bloemfontein.

Van Rensburg, A.P.J., 1980, Monumentaal die bouwerke ... 'n Halfeeu op die voorpos die verhaal van die onstaan, groei en prestasies van die ATKV (SAS en H), Caxton, n.p.

'Voortrekkersgedenkteken', Die Vaderland, 1936b, n.d., p. 7.

Voortrekker Monument Inauguration Committee, 1949, Inauguration of the Voortrekker Monument. Official Programme Pretoria, December 13-16, Voortrekkerpers, Johannesburg. 